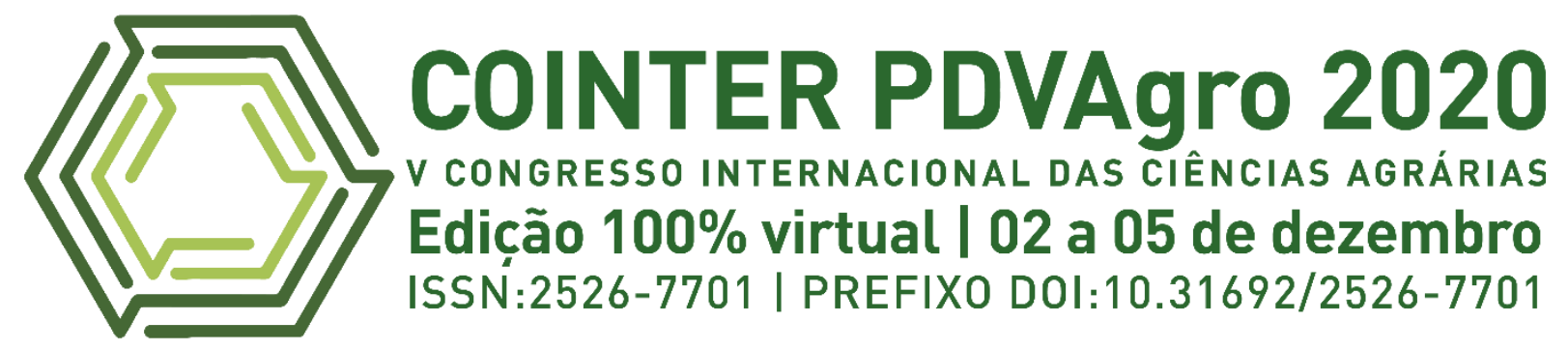

\title{
PROTOCOLO J-SYNCH EM BOVINOS DA AMÉRICA DO SUL: MANUSCRITO DE REVISÃO
}

\author{
PROTOCOLO J-SYNCH EN GANADO DE SUDAMÉRICA: \\ MANUSCRITO DE REVISIÓN
}

\section{J-SYNCH PROTOCOL IN SOUTH AMERICA CATTLE: REVIEW MANUSCRIPT}

Presentation: Oral Communication

\begin{abstract}
David Augusto Cavalcante de Oliveira ${ }^{1}$; Camille Gabriela Ramos Portal ${ }^{2}$;
Carlos Augusto Cavalcante de Oliveira ${ }^{3}$ Ariellen da Rocha Araujo ${ }^{4}$ Rinaldo Viana Batista ${ }^{5}$
\end{abstract}

DOI: https://doi.org/10.31692/2526-7701.VCOINTERPDVAgro.0243

\begin{abstract}
RESUMO
A inseminação artificial e os protocolos de IATF têm sido as principais estratégias empregadas para o avanço genético de rebanhos. Alguns desses protocolos buscam adaptações para o período de desenvolvimento folicular durante o proestro do ciclo reprodutivo de novilhas bovinas, já que muitos autores têm reportado a exposição a concentrações pré-ovulatórias de estradiol oriundas desse período como indutora do sucesso na prenhez e do desenvolvimento do concepto. O novo protocolo de $6 \mathrm{~d}$ com o uso de estradiol e progesterona (denominado J-Synch) se baseia no conceito de que o estradiol préovulatório do proestro pode desempenhar um papel no estabelecimento, desenvolvimento e suporte do embrião diretamente através da indução de receptores endometriais e regulação da secreção histotrófica e indiretamente através da subsequente fase lútea que prepara o ambiente uterino para suportar o embrião. Foi feita uma análise de achados de pesquisa em diversas plataformas utilizando palavras-chave. As primeiras pesquisas comparando J-Synch com os protocolos convencionais alcançaram ótimos resultados finais para o sucesso de prenhez, mas nenhuma diferença foi obtida entre os tratamentos, o que mostra que esse protocolo pode ser tão convencional quanto outros. Foi possível observar que alguns fatores podem influenciar a eficácia do J-Synch, incluindo o uso da eCG comparando com o protocolo convencional; a detecção do estro para a IATF; a hora para realização da IATF; o bom estado de qualidade nutricional que varia nas diferentes sazonalidades; o tipo de sêmen que pode ser utilizado (convencional ou sexado); e a presença do CL no início do protocolo. Foi possível concluir que o protocolo J-Synch tem muitas oportunidades de melhorar a taxa de prenhez para IATF em diversas condições abordadas.
\end{abstract}

Palavras-Chave: IATF, Proestro, Estradiol, J-Synch, Prenhez.

\section{RESUMEN}

La inseminación artificial y los protocolos IATF han sido las principales estrategias utilizadas para el

\footnotetext{
${ }^{1}$ Veterinary Medicine, Ufra - Campus Belém, oliveiradavidcavalcante2019@gmail.com

${ }^{2}$ Veterinary Medicine, Ufra - Campus Belém, camilleramos6@gmail.com

${ }^{3}$ Agronomy and PIBIC Embrapa, Ufra - Campus Belém, augustocavalcantecarlos@gmail.com

${ }^{4}$ Veterinary Medicine, Ufra - Campus Belém, ariellen21hoshi@gmail.com

${ }^{5}$ Ph.D. Animal Reproduction, Ufra - Campus Belém, rinaldobaptistavianna@gmail.com
} 


\title{
J-SYNCH PROTOCOL
}

avance genético de los rebaños. Algunos de estos protocolos buscan adaptaciones para el período de desarrollo folicular durante el proestro del ciclo reproductivo de novillas bovinas, ya que muchos autores han informado que la exposición a concentraciones preovulatorias de estradiol de ese período induce el éxito en el embarazo y el desarrollo del feto. El nuevo protocolo $6 \mathrm{~d}$ con el uso de estradiol y progesterona (llamado J-Synch) se basa en el concepto de que el estradiol puede jugar un papel en el establecimiento, desarrollo y apoyo del embrión directamente a través de la inducción de receptores endometriales y la regulación de la secreción histotrófica e indirectamente. a través de la fase lútea posterior que prepara el entorno uterino para sostener al embrión. Se realizó un análisis de los resultados de la investigación en varias plataformas utilizando palabras clave. La primera investigación que comparó J-Synch con protocolos convencionales logró excelentes resultados finales para el éxito del embarazo, pero no se obtuvieron diferencias entre los tratamientos, lo que demuestra que este protocolo puede ser tan convencional como otros. Se pudo observar que algunos factores pueden influir en la efectividad de J-Synch, incluido el uso de eCG en comparación con el protocolo convencional; detección de celo para la IATF; el momento de realizar la IATF; el buen estado de la calidad nutricional que varía en las diferentes estaciones; el tipo de semen que se puede utilizar (convencional o sexado); y la presencia de CL al inicio del protocolo. Se concluyó que el protocolo JSynch tiene muchas oportunidades para mejorar la tasa de embarazo para IATF bajo varias condiciones abordadas.

Palabras Clave: IATF, Proestro, Estradiol, J-Synch, embarazo.

\begin{abstract}
Artificial insemination and TFAI protocols have been the main strategies used for the genetic advancement of herds. Some of these protocols aim adaptations for the period of follicular development during the proestrus of the reproductive cycle of bovine heifers because many authors have reported the pre-ovulatory estradiol concentrations exposure from that period as inductor of the pregnancy success and the development of the fetus. The new $6 \mathrm{~d}$ protocol with the use of estradiol and progesterone (named J-Synch) bases on the concept estradiol may play a role in the establishment, development, and support of the embryo directly through the induction of endometrial receptors and regulation of histotrophic secretion and indirectly through the subsequent luteal phase that prepares the uterine environment to support the embryo. An analysis of research findings was made on several platforms using keywords. The first researches comparing J-Synch with conventional protocols achieved excellent end results for pregnancy success, but no difference was obtained among treatments, which shows that this protocol can be as conventional as others. It was possible to observe that some factors may influence the effectiveness of J-Synch, including the use of eCG compared to the conventional protocol; estrus detection; the time to perform the IATF; the appropriate nutritional quality status that varies in different seasons; the type of semen that may be used (either conventional or sexed-sorted); and the presence of CL at protocol starts. It was concluded the J-Synch protocol has many opportunities to improve the pregnancy rate for IATF under several conditions approached.
\end{abstract}

Keywords: FTAI, Proestrus, Estradiol, J-Synch, Pregnancy.

\section{INTRODUCTION}

Artificial insemination (AI) has been one of the most biotechnology adopted and consists of a technique whereby living sperm semen is collected from the breeder male and inserted in the female reproductive tract at suit time (for review see VISHWANATH, 2003). It was verified that AI gives birth a normal calving (for review see LAMB et al., 2015; PAUL and PRAKASH, 2005; GEARY et al., 1998; FILHO et al., 2011). Throughout this process, semen is inseminated in the target female, inserting a part of it within a collected or diluted shape in the cervix or uterus by a mechanical process at the suit time and in the most hygienic conditions (VISHWANATH, 2003). AI has been characterized to be a simple operation and 
does not dependent upon high cost. Synchronization of ovulation and AI has been considered as "the most powerful and applicable" technique for genetic improvement in cattle herd (SEIDEL, 1995; VISHWANATH, 2003). AI began to be exercised in the 50's decade in the USA and nowadays consists of the most technology used worldwide for genetic advance in cattle (VISHWANATH, 2003; SEIDEL, 1995).

Estrus (or heat) detection is hard and less efficient (FILHO et al., 2011; BRIDGES et al., 2014), thereby needing Fixed-Time Artificial Insemination (FTAI). FTAI protocols allow cows may be concurrently inseminated over the same time period, thus giving up of estrus detection. Ideally, FTAI will induce a compact estrus response at a predetermined time. Decreases in both the frequency of undesirable recessive genes and the diffusion of germplasms that are proven to be superior into myriad regions where its breeding would not be possible are some advantages pointed out for the use of this biotechnology. Many other advantages of FTAI have been echoed, including increases in the reproductive efficiency and PS (Pregnancy Success) rate, lack of needing heat detection and induction of cyclicity of cows in anestrum, varying worldwide depending on cattle markets, infrastructure, production systems, and climate (LAMB et al., 2016). Some requirements include cows after 40 days or more from post-calving and with a good body score and nutritional management and the use of only semen from highly fertile bulls.

There have been myriad studies concerning FTAI protocol for cattle in South American obtaining great PS results, for about 50\% or more (for review see BÓ et al., 2018). Because of myriad research findings about the effect of high preovulatory estradiol concentrations upon embryo development and pregnancy establishment (BRIDGES et al., 2010; NORTHROP et al., 2018; for review see POHLER, 2012; BRIDGES et al., 2014; BARTON et al., 1981), there has been suggestions advanced concerning protocol extending proestrus period [defined in FTAI as from CIDR (Controlled Internal Drug Release) removal to follicular ovulation]. There was an adaptation in CO-Synch protocol from $7 \mathrm{~d}$ to $5 \mathrm{~d}$ as an attempt aiming to verify this suggestion, which reduced CIDR maintenance (from CIDR insertion to CIDR removal) from $7 \mathrm{~d}$ to $5 \mathrm{~d}$ for the purpose to prolong proestrus period. Bridges et al. (2008) conducted an experiment in which cows were synchronized with either a 7d COSynch or 5d CO-Synch + CIDR program, with FTAI plus GnRH occurring at either $60 \mathrm{~h}$ (for those within $7 \mathrm{~d}$ CO-Synch) or $72 \mathrm{~h}$ (for those within $5 \mathrm{~d}$ CO-Synch) after CIDR removal. The PS rate were greater for the $5 \mathrm{~d}$ than $7 \mathrm{~d}$ program $(13.3 \%$ vs. $9.1 \%, \mathrm{P}<0.05)$. Furthermore, in another FTAI finding, animals undergoing long proestrus were significantly higher than the animals in the short proestrus period $(50 \%$ vs. $2.6 \%$ respectively, $\mathrm{P}<0.05$; BRIDGES et al., 


\section{J-SYNCH PROTOCOL}

2010).

In the year 2012, there was an approach of a new shortened estradiol/P4-based program of $6 \mathrm{~d}$ in South America. Shortened 6d estradiol/P4-based (named J-Synch) has currently been a consistent treatment method that has obtained comparable or more satisfactory outcomes comparing with others treatments, given that by this new protocol developed has been created opportunities to improve the PS in cattle (for review see BÓ et al., 2018). J-Synch consists of extending the proestrus period (duration of $72 \mathrm{~h}$ ) and reduction in CIDR maintenance (duration of $6 \mathrm{~d}$ ) in order to reach great increases in the preovulatory estradiol concentrations exposure. De la Mata and Bó (2012) conducted the primer description of effectiveness for J-Synch comparing with $5 \mathrm{~d}$ CO-Synch and achieved similar grate pregnancy rates among protocols. Respect the action of estradiol, Northrop et al. (2018) make a molecular approach pointing out that glucose transporter expression in the endometrium and glucose and protein concentration in uterine lumen were influenced by preovulatory estradiol concentrations and conceptus presence. The few research findings to date reviewing approaches about the efficacy of J-Synch protocol for cattle in relationship to the PS for situations varied led to this study. The leading purpose of this review manuscript is to conduct an analysis regarding the opportunities to improve the PS in heifers within J-Synch treatment in American south cattle, which may contribute to future researches aiming to develop improvements on the PS in cattle. It was hypothesized that the treatment may be more beneficial than conventional protocols when undergoing set conditions.

\section{THEORETICAL FOUNDATION}

The greatest preovulatory estradiol and postovulatory progesterone occur by the modulation of estradiol and progesterone receptors (DE LA MATA et al., 2018; POHLER, 2012), preparing the uterine environment to receive the embryo and establish the pregnancy. Bridges et al. (2012) stressed alpha estradiol receptor concentration in the endometrium was lower for low E2 animals than high E2 animals. Beyond both the influence on oocyte competence and the proliferation of granule cells, proestrus estradiol contributes for the uterine environment as well (POHLER, 2012), as pointed out in an experiment whereby it was indicated that the estradiol induces endometrial receptors and expression of numerous uterine proteins (BARTOL et al., 1981; BAUERSACHS et al., 2005; GORE 1994), regulating the oviductal histotroph secreted and readying uterine environment throughout the estrous cycle. Histotroph consists of a complex molecule mixture of enzymes, growth factor, cytokines, hormones, protein, and glucose, which is secreted or transported to the uterine 
lumen fluid (ULF). Regarding to the protein histotroph, cows impregnated had greater protein concentration in the ULF (NORTHROP et al., 2018) as well as ewes not receiving estradiol to stimulate preovulatory estradiol reduced total content of protein in ULF, reduced estradiol and progesterone receptors and had unsuccessful pregnancy (POHLER, 2012).

The glucose will act proliferating the trophoblast of the blastocyst and inducting its functions (i.e., nutrition and subsequent implantation on endometrium) as the main energy source for the embryo development (used by conceptus to make glycogen, nucleic acids, protein, and lipids during implantation period) (for review see GAO et al., 2009; LEESE et al., 1984). The glucose is transported from plasma to the endometrial epithelial cells by a facilitative, whereas glucose is delivered from endometrial epithelial cells to uterine lumen by a sodium-dependent transport (suggested in pregnancy sheep) (GAO et al., 2009).

Preovulatory estradiol may also play an indirect role in the uterine environment on the luteal phase secretions. Research findings performed with the J-Synch reported increases in postovulatory progesterone concentrations compared with the conventional short proestrus (DE LA MATA et al., 2016, 2016; BRIDGES et al., 2010). De la Mata (2016) stressed the size of corpus luteum (CL) after ovulation and progesterone serum concentration at day 12 after the ovulation was greater in heifers that received J-Synch than those in the conventional $7 \mathrm{~d}$ program in Bos Taurus. Because CL is a continuation of follicular maturation, preovulatory estradiol concentrations lead to effects on luteal lifespan or progesterone production. By the stimulation of CL progesterone, the permanence period of the blastocyst on oviduct for about 4 to 5 days conceives time for the endometrial glands to secrete histotroph (SPENCER and BAZER, 2002). Many authors have reported the end results of progesterone supplementations post ovulation (GARRET et al., 1988; SPENCER et al., 2004). These researches show there was no amount defined known of progesterone to establish and support pregnancy in cattle (POHLER et al., 2012).

Therefore, the J-Synch treatment suggests the prolongation of proestrus in order to increase the time of the estradiol effects on uterine histotroph secretions over both follicular and luteal phase, which ensure an appropriate embryo development and a subsequent PS.

\section{METHODOLOGY}

It was carried out an analysis with research findings approaching mainly results for JSynch treatment and effects of the estradiol and progesterone on the uterine environment. It was consulted numerous platforms, including Google Scholar, Springer, Elsevier, ResearchGate, and SciELO. The key-words used for the investigation were "Artificial 


\section{J-SYNCH PROTOCOL}

Insemination", "estradiol + uterine environment", "FTAI with estrus detection" and "JSynch" in sequence. Some of these words were substituted by its synonymous and its Spanish and Portuguese correspondent.

\section{RESULTS AND DISCUSSION}

This study was designed to evaluate the success in synchronization of heifers/cows with the J-Synch protocol. In conventional estradiol/P4-based protocol, heifers usually receive Estradiol Benzoate (EB) concurrently with CIDR insertion (Day 0) in order to synchronize follicle source emergence due to atresia. On days 7, 8, or 9, luteolysis is ensured by PGF2 alpha dose [applicating or not Estradiol Cypionate (EC) or eCG concurrently] at CIDR removal. Thereafter, GnRH, LH, or EB (the GnRH dose commonly occurs at FTAI) is administered at some time interval after CIDR removal (48h, 60h, or $72 \mathrm{~h}$ ) to synchronize ovulation. Santos et al. (2018) reported great PS rate in cows treated with the conventional BE at $8 \mathrm{~d}$ and $9 \mathrm{~d}$ (basic protocol in which BE is administered concurrently with CIDR removal at 8 and 9 days, respectively) and was able to synchronize for about $85 \%$ females. Respect the JSynch protocol, it is similarly administered EB at CIDR insertion; PGF2 alpha with singledose; CIDR maintenance time decreases to 6 days; while the proestrus period increases $(72 \mathrm{~h})$ with the view to prolong estradiol exposure (BÓ et al., 2018). A description of this protocol may be view in Figure 01 and Chart 01.

Figure 01: Experimental draw of new shortened estradiol/P4-based (J-Synch) protocol. There is a reduction in CIDR maintenance (6d) and an extending proestrus period (72h) in order to reach great increases in the preovulatory estradiol concentrations exposure.

\section{$\mathrm{EB}(2 \mathrm{mg})$}

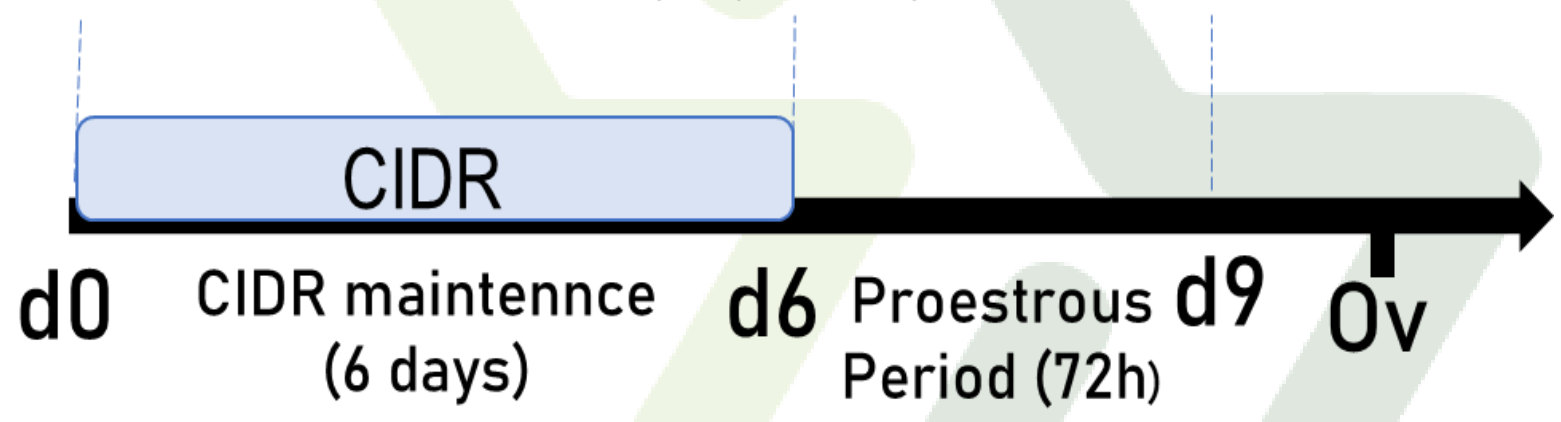

Fonte: adapted from Bó et al., 2018 (2020). 
Chart 01: Occurrences in proceeding for J-Synch program X Effects on follicular dynamic.

\begin{tabular}{|c|c|c|}
\hline Day & Occurrence & Effect \\
\hline 0 & EB (2mg) and CIDR insertion & Synchronization of follicular waves by atresia \\
\hline 6 & PGF2 alpha (single dose) and CIDR removal & Luteolysis \\
\hline 6 to 9 & Proestrus period & Preovulatory estradiol concentrations exposure \\
\hline 9 & GnRH $(2 \mathrm{mg})$ and FTAI & Synchronization of the ovulations \\
\hline
\end{tabular}

Fonte: own source (2020)

De la Mata et al. (2012) indicated similar durations of the period from CIDR removal to ovulation for heifers treated with J-Synch $(97.1 \pm 17.4$ h vs. $95.1 \pm 12.4$ h respectively, $\mathrm{P}>$ 0.05) comparing with conventional estradiol/P4-based protocol, while another experiment (BÓ et al., 2018) showed duration more prolonged (103.8 $\pm 8.3 \mathrm{~h}$ vs. 82.7 3.1h, $\mathrm{P}=0.01$ ) in line with results by De la Mata (2016) that showed a difference for about $28 \mathrm{~h}(93.7 \pm 12.94 \mathrm{~h}$ vs. $65,0 \pm 13,67 \mathrm{~h}, \mathrm{P}=0.0001)$ than conventional protocol. It may evidence heifers treated with $\mathrm{J}$ Synch usually ovulate later than those treated with conventional estradiol/P4-based protocol due to the proestrus extended to $72 \mathrm{~h}$.

Respect the PS, several studies have pointed out a PS rate improved for heifers treated with the J-Synch to FTAI (DE LA MATA et al., 2016; BRIDGES et al., 2010; BÓ et al., 2018) and to FTET (Fixed-Time Embryo Transfer) (MENCHACA et al., 2017) compared to the conventional estradiol/P4-based protocol, while others have approached no differences among shortened and conventional protocols (DOMINICIS et al., 2020; NORTHROP et al., 2018; DE LA MATA and BÓ., 2012; RÉ et al., 2013; PÉREZ-MORA et al., 2020). 28 Bos taurus heifers with 16 to 17 years old were used for an experiment comparing J-Synch protocol with the CO-Synch 5d (DE LA MATA and BÓ, 2012; BÓ et al., 2018; MOTTA et al., 2016), 14 were treated with the proceedings for the J-Synch while other 14 within the COSynch 5d groups received CIDR one day after J-Synch receive. It was obtained a great PS rate among the treatments but without statistical difference (50.0\% vs 57.1\%). Furthermore, in an experiment carried out to compare J-Synch, 5d CO-Synch, and the conventional 7d EB, it was obtained great outcomes for the PS but without statistical difference as well (62.7\% vs 54.5\% vs 53.4\%, respectively) (RÉ et al., 2013; BÓ et al., 2018). Those dates suggest J-Synch may reach results as conventional as other treatments, creating new opportunities and combinations of tactics with the view to improve the FTAI use.

The use of eCG has been plenty used for several FTAI protocols for the proposition to increase the dominant follicle growth rate, thereby administered commonly at CIDR removal. The study of Pérez-Mora (2020) led an analysis comparing the J-Synch and the conventional program using $300 \mathrm{IU}$ eCG at CIDR removal in both treatments, concluding that J-Synch 


\section{J-SYNCH PROTOCOL}

tended to have lower embryo loss than other treatment $(4.17 \%$ vs. $8.67 \%$ respectively, $\mathrm{P}=$ 0.0989); however, the PS rate did not differ (51.01\% vs. $47.17 \%$ respectively, $\mathrm{P}=0.4453$ ). Other two researches were performed with the view to observe the PS among protocol with the use of eCG (BÓ et al., 2018, 2016). In experiment 1, cows were separated off in two groups within the same protocol (J-Synch), one receiving and other not receiving eCG, whereas in another experiment, all animals receive eCG and were segregated off in J-Synch and conventional programs (similar to that one performed by Pérez-Mora et al., 2020). The PS for experiment 1 (57.1\% vs. 53.1\%, respectively) and 2 (56.1\% vs. 50.7\%, respectively) obtained statistical difference, which evidence that eCG use improves the outcome of J-Synch treatments (embryo loss and PS) due to the increase in the growth rate of the dominant follicle from CIDR removal to FTAI and GnRH administration, thus increasing the estradiol exposure following ovulation.

The protocol may be matched with the estrus detection, given that by the effects of exhibition of estrus at FTAI on pregnancy establishment had ever been reported (FILHO et al., 2011; BRIDGES et al., 2014; LARIMORE et al., 2015) and may be assisted by tailpaint/patches use at CIDR removal, in which tail-paint/patches rubbed off indicates estrus detection, while tail-paint/patches intact shows estrus not detect. Although heat detection is not required for the synchronization protocols, heifers showing signs of estrus activities have a better PS than those not exhibiting signs of estrus (BRIDGES et al., 2014). To prove JSynch provides an appropriate PS rate, it was performed a trial using estrus detection within both J-Synch and conventional protocols. Heifers were FTAI in either a conventional protocol with EB at $8 \mathrm{~d}$ or J-Synch. There was no difference in the PS rates, but heifers in the J-Synch showing estrus tended to achieve higher PS rate than conventional group $(80.0 \%$ vs $50.0 \%, \mathrm{P}$ $<0.1$ ) and had higher PS rate than those within J-Synch not showing estrus (BÓ et al., 2018), which supports the J-Synch fundament based on effects of estradiol concentrations on subsequent conception. However, in a second study aiming to determine differences in the PS for animals in the conventional and the J-Synch treatment showing estrus, it was inseminated 396 heifers in either a conventional protocol with ECP or J-Synch using eCG. The PS rate was also not different among protocols, but those displaying estrus had a higher PS rate only in the conventional protocol. The incoherent outcomes among those studies may probably be explained by either ECP use or the different time to inseminate ( $54 \mathrm{~h}$ and $48 \mathrm{~h}$ ) for animals not exhibiting estrus within the conventional groups.

There have been myriad trials aiming to find out handling pathways to achieve appropriate application of the J-Synch protocol. In order to determine effects of time to 
inseminate after the CIDR removal (60h or $72 \mathrm{~h}$ ) based on reproductive status (presence of estrus) on subsequent establishment and support of pregnancy, a study verified results of the PS for 1) animals showing and not showing estrus at 60h and FTAI at that time, and for 2) animals FTAI at $72 \mathrm{~h}$ regardless of reproductive status. Heifers showing estrus at $60 \mathrm{~h}$ and FTAI at that time had PS rate similar to those FTAI at 72h, i.e. heifers undergoing J-Synch may be FTAI early (prior to 72h) without compromising PS; while it was, nonetheless, observed that heifers FTAI at $72 \mathrm{~h}$ had higher PS rate than those not showing estrus and AI at $60 \mathrm{~h}$. Furthermore, the needless of GnRH dose for heifers exhibiting estrus at $60 \mathrm{~h}$ have been reported (BÓ et al., 2018). Those dates may reveal that the appropriate application of that protocol occurs in double handling, one at $60 \mathrm{~h}$ and other $72 \mathrm{~h}$ post device removal with tailpaint and patches use for estrous detection (BÓ et al. 2018), consisting of: the cattle herd receive EB ( $2 \mathrm{mg}$ ) on day 0 and insert CIDR in until day 6 in conjunction with a PGF2 alpha dose. Thereafter, a part of the herd showing signs of estrus (tail-paint rubbed off $>30 \%$ ) at $60 \mathrm{~h}$ may be inseminated at that time (due to the PS is similar to those inseminate at $72 \mathrm{~h}$ ) and do not receive GnRH (due to the needless of $\mathrm{GnRH}$ for heifers exhibiting estrus at 60h), whereas those with the tail-paint intact at $60 \mathrm{~h}$ may be FTAI at $72 \mathrm{~h}$ (because the PS for $72 \mathrm{~h}$ is better than $60 \mathrm{~h}$ ) and receive GnRH. At $72 \mathrm{~h}$, heifers not showing heat at $60 \mathrm{~h}$ is inseminated (BÓ et al., 2018).

In the other hand, estrus presence at FTAI is not, nonetheless, the sole determinant of the PS, due to the fact the impact of a short-term increase in energy intake on the numbers of cows cycling or pregnancy rate may be dependent upon the previous nutritional status of the cow (BINDARI et al., 2013) influencing directly its body conditions. Three experiments were carried out in order to assess the outcome of the nutritional quality variable upon the PS rate for heifers synchronized with J-Synch comparing with the conventional protocol in either winter and spring fields. In an experiment performed in winter, heifers within J-Synch had lower PS rate than those within conventional treatment $(37.8 \%$ vs. $49.3 \%$ respectively, $\mathrm{P}=$ 0.008), whereas a second experiment carried out in spring reported animals within J-Synch had a similar PS rate (59.7\% vs. 53.1\% respectively, $\mathrm{P}=0.12)$ and an experiment 3 in spring as well evidenced a greater PS rate $(67.9 \%$ vs. $46.6 \%$ respectively, $\mathrm{P}=0.006)$ than those within the conventional (DE LA MATA, 2016; BÓ et al., 2018). The incoherent results among those researches may be interpreted by a distinction in the availability of fodder paddock due to fields variated. In winter there was a low amount of suitable fodder while in spring there was feed ad libitum, which have a direct effect upon nutritional status and body conditions (BINDARI et al., 2013). Therefore, the low pregnancy establishment in the assay 


\section{J-SYNCH PROTOCOL}

performed in winter has the prospect to be occurred due to a non-appropriate nutritional quality.

A question that may be raised is whether the sexed-sorted semen may improve the PS for cattle synchronized with the J-Synch treatment. An alternative to match that protocol with the sexed-sorted semen use consists of the tail-paint/patches use and eCG dose at CIDR removal and detection of estrus at $60 \mathrm{~h}$. In this method, heifers showing estrus at $60 \mathrm{~h}$ and $72 \mathrm{~h}$ are FTAI at $72 \mathrm{~h}$ with sexed-sorted semen, while those not showing estrus at $72 \mathrm{~h}$ are FTAI with the conventional or sexed semen at $84 \mathrm{~h}$ plus GnRH administration (BÓ et al., 2018). A research compared J-Synch treatment receiving $400 \mathrm{IU}$ eCG at CIDR removal using 877 Angus or Angus crossbred cows with either sexed or non-sexed (conventional) semen. Cows with the tail paint rubbed off by 60 or $72 \mathrm{~h}$ after CIDR removal were FTAI at $72 \mathrm{~h}$ with either sexed or conventional semen. Those not showing estrus by $72 \mathrm{~h}$ received $\mathrm{GnRH}$ at $72 \mathrm{~h}$ and were AI with either sexed-sorted or conventional semen at $84 \mathrm{~h}$ plus GnRH dose. Among cows FTAI with sexed-sorted semen, those inseminated at $84 \mathrm{~h}$ showing estrus had the greatest results for the PS rate, whereas no differences were detected among cows FTAI with conventional semen. Furthermore, the PS rate was lower for sexed-sorted than the conventional semen (45.3\% vs. $68.6 \%$ respectively, P < 0.01) (GABRIEL et al., 2019; BÓ et al., 2018). Bó et al. (2018) conducted an analysis concluding sexed-sorted semen may be adapted for FTAI protocols, but PS is lower than conventional semen.

Another question that may be raised is whether the pubertal attainment before the breeding season influences the PS. An experiment carried out by Bridges et al. (2014) demonstrated heifers failing to reach puberty (absence of CL) at protocol initiation had PS to FTAI reduced comparing with those having multiple estrus cycles (presence of CL) prior to breeding season, irrespective of treatment. To assess the PS rate and verify pubertal status in Nelore heifers, it was performed a J-Synch pre-synchronized with long-term P4 (LIMA et al., 2017), which may be an occasion to verify the effects of puberty on PS to J-Synch. On day 22, heifers were classified in pubertal and prepubertal and were randomly divided off to receive (treatment) or not (control) P4 dose on d-22. Thereafter it was performed the J-Synch with an additional administration of PGF2 alpha on day 0 (due to pre-synchronization prior to J-Synch). It was obtained that 1) among pubertal heifers, the proportion for the treatment group was $91.2 \%$, whereas $79.5 \%$ for control, i.e. the proportion of heifers with the CL on day 0 was better to treatment than control 2) the PS rate was $42 \%$ and tented to be influenced by treatment 5) Control heifers had lower estrus expression that heifers treated. So, the pre- 
synchronization with long-term P4 carried out prior to normal J-Synch may be an opportunity to increase the proportion of heifers pubertal at protocol initiation and the subsequent PS.

\section{CONCLUSIONS}

FTAI has been used with the view to improve pregnancy success through hormonal treatments. Several variations emerged, including the J-Synch protocol which aims to increase the time of preovulatory estradiol exposure to improve embryo establishment by preparation of uterine environment for pregnancy. The end results for pregnancy success have been comparable or more beneficial than conventional programs. The eCG use may be a chance to improve pregnancy through an increase in growth dominant follicle. The presence of estrus at FTAI has been reported for many authors and can be applied for J-Synch. The protocol has applicability established on double management that works based on estrus exhibiting on first management. Furthermore, a nice nutritional quality status, the type of semen at FTAI, and the pre-synchronization to achieve a high proportion of cycling heifers have been also factors that may contribute to a FTAI well-done. It was concluded the treatment may be more beneficial than conventional protocol when undergoing many of those conditions, thereby needing future researches combining those opportunities to improve pregnancy success in order to obtain more results to study and experimented. Finally, the possibility whereby that protocol may be well-done for another species, including mainly buffaloes, should not be forgotten.

\section{REFERENCES}

Bartol FF, Thatcher WW, Lewis GS, Bliss EL, Drost M, Bazer FW. Effect of estradiol 17beta on PGF and total protein content in bovine uterine flushings and peripheral plasma concentration of 13, 14-dihydro-15-ketoPGF(2alpha). Theriogenology 1981; 15:345-358.

Bauersachs S, Ulbrich SE, Gross K, Schmidt SE, Meyer HH, Einspanier R, Wenigerkind H, Vermehren M, Blum H, Sinowatz F, Wolf E. Gene expression profiling of bovine endometrium during the oestrous cycle: detection of molecular pathways involved in functional changes. J Mol Endocrinol 2005; 34:889-908.

Bindari Y. R., Shrestha S., Shrestha N., Gaire T. N.: Effects of nutrition on reproduction - A review. Adv. Appl. Sci. Res. 2013, 4, 421-429.

BO, G. A.; HUGUENINE, E. E.; LAMATA, J. J. de; CARNEIRO, R. L. R. de; MENCHACA, A.. 7 Pregnancy rates in suckled beef cows synchronized with a shortened progesterone/oestradiol-based protocol (J-synch) and inseminated with conventional or sexedsorted semen. Reproduction, Fertility And Development, [S.L.], v. 31, n. 1, p. 129-129, 2019. CSIRO Publishing. 
BÓ, Gabriel \& Huguenine, Emilio \& DE LA MATA, José \& Núñez Olivera, Richard \& Baruselli, Pietro \& Menchaca, Alejo. (2018). Programs for fixed-time artificial insemination in South American beef cattle. Animal Reproduction. 15. 952-962. 10.21451/1984-3143AR2018-0025.

BRIDGES G.A., Helser L.A., Grum D.E., Mussard M.L., Gasser C.L., Day M.L. (2008). Decreasing the interval between GnRH and PGF2 $\alpha$ from 7 to 5 days abs lengthening proestrus increases timed-AI pregnancy rates in beef cows. Theriogenology 69: 843-851.

BRIDGES G.A., Mussard M.L., Burke C.R., Day M.L. (2010). Influence of the length of proestrus on fertility and endocrine function in female cattle. Animal Reproduction Science 117: 208-215.

BRIDGES G.A., Mussard M.L., Pate J.L., Ott T.L., Hansen T.R. and Day M.L. (2012). Impact of preovulatory estradiol concentrations on conceptus development and uterine gene expression. Animal Reproduction Science 133: 16-26.

BRIDGES G.A., Mussard M.L., Hesler L.A., Day M.L. (2014). Comparison of follicular dynamics and hormone concentrations between the 7-day and 5-day CO-Synch + CIDR program in primiparous beef cows. Theriogenology 81: 632-638.

DE LA MATA JJ, BÓ GA. Estrus synchronization and ovulation using protocols with estradiol benzoate and GnRH and reduced periods of insertion of a progesterone releasing device in beef heifers. Taurus 2012;55: 17-23.

DE LA MATA J.J. (2016). Prolongación del proestro y reducción del periodo de inserción del dispositivo con progesterona en vaquillonas para carne inseminadas a tiempo fijo. Universidad Nacional de Córdoba, pp 38-56.

DE LA MATA JJ, Núñez-Olivera F, Cuadro F, Bosolasco D, de Brund V, Meikle A, BÓ GA Menchaca A. 2018. Impact of extending the proestrus length in an oestradiol and progesterone-based oestrus synchronization program on follicular and luteal development, uterine gene expression, and protein localization, and pregnancy rates in beef heifers. Reprod Fertil Dev.

Dixon RE, Buttram VC. Artificial insemination using donor semen: a review of 171 cases. Fertil Steril. 1976 Feb;27(2) 130-134. PMID: 1248658.

Dominicis, O., et al. "Efecto del tratamiento J-Synch sobre el porcentaje de preñez en vaquillonas para cría inseminadas a tiempo fijo." Revista Veterinaria, vol. 30, no. 2, 2019, p. 31+. Accessed 6 Sept. 2020.

Gabriel, B. O. (2020). Pursuit of a means of manipulating ovarian function in the cow: An adventure of serendipity, collaboration and friendship. Theriogenology. 150. 10.1016/j.theriogenology.2020.03.010.

Gao H, Wu G, Spencer TE, Johnson GA, Bazer FW. Select nutrients in the ovine uterine lumen. II. Glucose transporters in the uterus and periimplantation conceptuses. Biol Reprod 2009; 80(1):94-104. 
Garret JE, Geisert RD, Zavy MT, Morgan GL (1988) Evidence for maternal regulation of early conceptus growth and development in beef cattle. J Reprod Fertil 84:437-446.

GEARY, T.W.; WHITTIER, J.C.; THRIFT, F.A.; DOLEZAL, S.L.. Effects of a Timed Insemination Following Synchronization of Ovulation Using the Ovsynch or CO-Synch Protocol in Beef Cows. The Professional Animal Scientist, [S.L.], v. 14, n. 4, p. 217-220, dez. 1998. American Registry of Professional Animal Scientists

Gore-Langton RE, Armstrong DT (1994) Follicular steroidogenesis and its control. In: Knobil E, Neill JD 2nd (eds) The physiology of reproduction. Raven, New York, pp 571-627.

LAMB, G.C.; MERCADANTE, V.R.G.; HENRY, D.D.; FONTES, P.L.P.; DAHLEN, C.R.; LARSON, J.e.; DILORENZO, N.. Invited Review: advantages of current and future reproductive technologies for beef cattle production. The Professional Animal Scientist, [S.L.], v. 32, n. 2, p. 162-171, abr. 2016. American Registry of Professional Animal Scientists.

LARIMORE, E. L.; AMUNDSON, O. L.; BIRD, S. L.; FUNNELL, B. J.; KRUSE, S. G.; BRIDGES, G. A.; PERRY, G. A.. Influence of estrus at fixed-time artificial insemination on early embryonic development in beef cattle. Journal Of Animal Science, [S.L.], v. 93, n. 6, p. 2806-2812, 1 jun. 2015. Oxford University Press (OUP).

Leese HJ, Barton AM. Pyruvate and glucose uptake by mouse ova and preimplantation embryos. Reproduction 1984; 72(1):9-13.

LIMA, R. S.: Long-acting injectable progesterone for pre-synchronization of ovulation in Nelore heifers [Emprego de progesterona injetável de longa ação para pré-sincronização da ovulação em novilhas Nelore]. 2017. 86 f. Tese (Doutorado em Ciências) - Faculdade de Medicina Veterinária e Zootecnia, Universidade de São Paulo, Pirassununga, 2017.

Menchaca A, Núñez-Olivera R, García-Pintos C, Cuadro F, Bosolasco D, Fabini F, Dutra S, DE LA MATA JJ, BÓ GA. 2017. Effect of the prolongation of the proestrus in the fertility of the FTAI programs. Proceedings XII Symposium on Animal Reproduction. Institute of Animal Reproduction Cordoba (IRAC), Córdoba, Argentina, pp.191-216.

MION, Bruna; BONOTTO, Ramiro Martins; FARIAS, Caroline Oliveira; ROSA, Fernanda Souza; PRADIEE, Jorgea; ROVANI, Monique Tomazele; PEGORARO, Lígia Margareth Cantarelli; BONOTTO, Ana Lúcia Martins; PFEIFER, Luiz Francisco Machado; SCHNEIDER, Augusto. J-Synch protocol associated with estrus detection in beef heifers and non-lactating cows. Medicina Veterinária (Ufrpe), [S.L.], v. 13, n. 2, p. 269-274, 8 abr. 2019. Medicina Veterinaria (UFRPE).

Motta, Jessica Cristina Lemos; COLLI, Marcos Henrique Alcantara; PENTEADO, Luciano; et al. Taxa de prenhez à IATF de novilhas nelore e cruzadas submetidas ao protocolo J-Synch (6 DIAS). Anais. Jaboticabal: Sociedade Brasileira de Tecnologia de Embriões, 2016.

NORTHROP, Emmalee J; RICH, Jerica J J; A CUSHMAN, Robert; MCNEEL, Anthony K; SOARES, Émerson M; BROOKS, Kelsey; SPENCER, Thomas e; A PERRY, George. Effects of preovulatory estradiol on uterine environment and conceptus survival from fertilization to maternal recognition of pregnancy $\dagger$. Biology of Reproduction, [S.L.], v. 99, n. 3, p. 629-638, 


\section{J-SYNCH PROTOCOL}

17 abr. 2018. Oxford University Press (OUP).

Paul V, Prakash BS. Efficacy of Ovsync protocol for synchronization of ovulation and fixedtime artificial insemination of Murrah buffaloes (Bubalus bubalis). Theriogenology 2005; 1049-60.

PEREZ-MORA, Alfonso; SEGURA-CORREA, José Candelario; PERALTA-TORRES, Jorge Alonso. Factors associated with pregnancy rate in fixed-time embryo transfer in cattle under humid-tropical conditions of México. Anim. Reprod., Belo Horizonte, v. 17, n. 2, e20200007, 2020. $\quad$ Available from $<$ http://www.scielo.br/scielo.php?script=sci_arttext\&pid=S1984-

$31432020000200205 \& \operatorname{lng}=$ en\&nrm=iso > . access on 06 Sept. 2020.

POHLER, Ky G.; GEARY, Thomas W.; ATKINS, Jacqueline A.; PERRY, George A.; JINKS, Emma M.; SMITH, Michael F.. Follicular determinants of pregnancy establishment and maintenance. Cell and Tissue Research, [S.L.], v. 349, n. 3, p. 649-664, 18 mar. 2012. Springer Science and Business Media LLC.

SÁ FILHO, M.F.; SANTOS, J.e.P.; FERREIRA, R.M.; SALES, J.N.s.; BARUSELLI, P.s.. Importance of estrus on pregnancy per insemination in suckled Bos indicus cows submitted to estradiol/progesterone-based timed insemination protocols. Theriogenology, [S.L.], v. 76, n. 3, p. 455-463, ago. 2011. Elsevier BV.

Seidel, G.E. 1995. Reproductive biotechnologies for profitable beef production. Proceeding Beef Improvement Federation, Sheridan, WY, p 28.

Spencer TE, Bazer FW (2002) Biology of progesterone action during pregnancy recognition and maintenance of pregnancy. Front Biosci 7:1879-1898

Spencer TE, Johnson GA, Burghardt RC, Bazer FW (2004) Progesterone and placental hormone actions on the uterus: insights from domestic animals. Biol Reprod 71:2-10.

Vishwanath, R. (2003). Artificial insemination: The state of the art. Theriogenology. 59. 57184. 10.1016/S0093-691X(02)01241-4.

Motta JCL, Colli MHA, Penteado L, Bayeux BM, Mingoti RD, BÓ GA, Lugo LC, Rezende RG, Baruselli PS. Taxa de prenhez à IATF de novilhas nelore e cruzadas submetidas ao protocolo J-Synch (6 DIAS). Anais da XXX Reunião Anual da Sociedade Brasileira de Tecnologia de Embriões, Foz do Iguaçu, p.204, 2016. 